ОСОБЛИВОСТІ РОЗВИТКУ

СВІТОВОГО ГОСПОДАРСТВА ТА МЕВ

УДК339.98 - 339.96

SOVEREIGN WEALTH FUNDS IN THE SYSTEM OF GLOBAL FINANCIAL IMBALANCES: AN ANALYSIS OF BENEFITS AND THREADS FROM THE PERSPECTIVE OF GLOBAL FINANCIAL STABILITY

ФОНДИ СУВЕРЕННОГО БАГАТСТВА У СИСТЕМІ ГЛОБАЛЬНИХ ФІНАНСОВИХ ДИСБАЛАНСІВ: АНАЛІЗ ВИГОД ТА ЗАГРОЗ 3 ПОЗИЦІї ГЛОБАЛЬНОї ФІНАНСОВОї СТАБІЛЬНОСТІ

\begin{tabular}{|c|c|c|}
\hline $\begin{array}{c}\text { ФОНДЫ } \\
\text { ОБАЛЬНЫХ }\end{array}$ & СУВЕРЕННОГО & $\begin{array}{r}\text { БОГАТСТВА В } \\
\text { ДИСБАЛАНСОВ: }\end{array}$ \\
\hline ВЫГОДАХ И & УГРОЗАХ & ГЛОБАЛЬНО \\
\hline
\end{tabular}

Reznikova N.

Doctor of Economics, Associate Professor, Professor at the Chair of World Economy and International Economic Relations of Institute of International Relations Taras Shevchenko National University of Kyiv.Email: r_nv@ukr.net

Ivashchenko 0.

$\mathrm{PhD}$ (Econ.), Associate Professor, Head of Department of Economy and Management of Foreign Economic Activity of National Academy of Statistics, Accounting and Audit. E-mail: oi.nasoa@gmail.com

Резнікова Н.В.

Доктор економічних наук, доцент, професор кафедри світового господарства та міжнародних економічних відносин Інституту міжнародних відносин Київського національного університету імені Тараса Шевченка. E-mail: r_nv@ukr.net

Іващенко О.А.

Кандидат економічних наук, доцент, завідувач кафедри економіки та менеджменту зовнішньоекономічної діяльності Національної академії статистики, обліку та аудиту. Е-таil: oi.nasoa@gmail.com

Резникова Н.В.

Доктор экономических наук, доцент, професор кафедры мирового хозяйства и международных экономических отношений Института международных отношений Киевского национального университета имени Тараса Шевченко. E-mail: r_nv@ukr.net

\title{
Иващенко О.А.
}

Кандидат экономических наук, доцент, заведующий кафедрой экономики и менеджмента внешнеэкономическойд еятельности Национальной академии статистики, учета и аудита. E-mail: oi.nasoa@gmail.com

Abstract. A new active component has appeared in the contemporary global financial system, Sovereign Wealth Funds, demonstrating the growing investment capacities in some countries. This newly born category of investors reflects a wide array of economic policy intentions in the realities when current consumption or investment of considerable funds resulting from budget surplus and positive payment balance becomes either undesirable or unfeasible. The article's objective is to analyze operation of Sovereign Wealth Funds as an 
innovative and leading actor of the global financial market, coming in place of hedge funds and private investment funds and challenging the role of central banks as biggest lenders. The position of Sovereign wealth Funds in the system of global financial imbalances is studied; benefits and threats from their operation are analyzed from the perspective of global financial stability.

Keywords: sovereign wealth funds, global financial imbalances, financial stability, savings, investments.

Анотація. У сучасній глобальній фінансовій системі з'явився новий активний компонент, який демонструє наростаючі можливості у сфері інвестування окремих краӥн - фонди суверенного багатства. Поява даної категорії інвесторів відобразила широкий комплекс намірів в економічній політиці в реаліях, коли створюються фундаментальні передумови для небажаності чи неможливості поточного споживання або інвестування значних коштів, які є результатом надлишку бюджету та профіциту платіжного балансу. Мета статті в аналізі діяльності суверенних фондів багатства як новітнього провідного учасника світового фінансового ринку, який прийшов на зміну хедж-фондам і приватним інвестиційним фондам, поставивши під сумнів роль центральних банків як найбільших позичальників. Досліджено місие фондів суверенного багатства у системі глобальних фінансових дисбалансів та проаналізовано вигоди та загрози від їхньої діяльності з позиції глобальної фінансової стабільності.

3'ясовано, щу незалежно від задекларованих цілей, ФСБ фактично виступають дієвим актором реалізачї економічної політики. Крім того, формування додаткового фінансового забезпечення у вигляді таких фондів зумовлене необхідністю гарантування майбутніх державних витрат, пов'язаних зі старінням населення та пошуком адаптивної сочіальної моделі. Отож, експансія фондів суверенного багатства є відображенням поєднання глобальних фінансових дисбалансів, глобальної фінансової інтеграчії та нових можливостей у сфері глобального інвестування.

Ключові слова: фонди суверенного багатства, глобальні фінансові дисбаланси, фінансова стабільність, заощадження, інвестиції.

Аннотация. В современной глобальной финансовой системе появился новый активный компонент, который демонстрирует нарастающие возможности в сфере инвестирования отдельных стран - фонды суверенного богатства. Появление данной категории инвесторов отразила широкий комплекс намерений в экономической политике в реалиях, когда создаются фундаментальные предпосылки для нежелательности или невозможности текущего потребления или инвестирования значительных средств, полученных в результате избытка бюджета и профицита платежного баланса. Цель статьи в анализе деятельности суверенных фондов богатства как нового ведущего участника мирового рынка, который пришел на смену хедж-фондам и частным инвестиционным фондам, поставив под сомнение роль центральных банков как крупнейших заемщиков. Исследовано место фондов суверенного богатства в системе глобальных финансовых дисбалансов и проанализированы выгоды и угрозы их деятельности с позищии глобальной финансовой стабильности.

Установлено, что независимо от задекларированных иелей, ФСБ фактически выступают действенным актером реализации экономической политики. Кроме того, формирование дополнительного финансового обеспечения в виде таких фондов обусловлено необходимостью обеспечения будущих государственных расходов, связанных со старением населения и поиском адаптивной социальной модели. Итак, экспансия фондов суверенного богатства является отражением сочетания 
глобальных финансовых дисбалансов, глобальной финансовой интеграции и новых возможностей в сфере глобального инвестирования.

Ключевые слова: фонды суверенного богатства, глобальные финансовые дисбалансы, финансовая стабильность, сбережения, инвестиции.

The current problem. The growing economies have increased their financial assets and the accumulated national wealth, claiming for the role of active players at international financial markets. At the same time, transformation of Sovereign Wealth Funds (SWFs) into institutions active at the global market have changed the base of the global investors, thus modifying a wide array of processes taking place in the sphere of global finance $[1, \mathrm{p} .423]$.

The aim of the article is to analyze benefits and threats related with SWF operation for the financial stability.

Analysis of the latest publications.Evidence for the potential radical consequences of SWFs operation for the established balance of power on the global arena can be found in the monograph of V. Kozyuk, a Ukrainian researcher. Yet, in the list of risks enumerated by the author,we can discern the signs of the transformation of economic dependence into economic interdependence with the changing vectors of mutual impact. J. Santiso, OECD Development Centre' Director, notes thatSWFs are the products of a major global economic and financial rebalancing of power. Their emergence has been controversial not only because of the fear of politically induced investments, lack of transparency and other conspiratorial arguments, but also because they symbolize a much deeper phenomenon reshaping the world's economy and finance [13]. Although there exists no commonly accepted definition of SWFs, R. Beck and M. Fidora identifyythree elements that are common to such funds: first, SWFs are state-owned. Second, SWFs have no or only very limited explicit liabilities and, third, SWFs are managed separately from official foreign exchange reserves[9]. B. Bortolotti, V. FotakandW. L. Megginsonasserts, that there is no consensus, in either the academic or practitioner literature, on exactly what constitutes a SWF.The authors use the definition of SWF employed by the Sovereign Investment Lab: (1) an investment fund rather than an0 operating company; (2) that is wholly owned by a sovereign government, but organized separately from the central bank or finance ministry to protect it from excessive political influence; (3) that makes international and domestic investments in a variety of risky assets; (4) that is charged with seeking a commercial return; and (5) which is a wealth fund rather than a pension fund-meaning that the fund is not financed with contributions from pensioners and doesnot have a stream of liabilities committed to individual citizens [10].

In spite of great numbers of studies devoted toSWFs analysis from the perspective of their organization structure, management specifics, comparisons of existing SWF operation models at country level and their formation sources, a study of SWF impact from the perspective of SWF capacity to aggravate or eliminate global imbalances requires rethinking.

The important research results.The increasing numbers and scopes of SWFs in the globalization era reflect the occurrence of high surpluses both in countries exporting primary resources and in ones importing SWFs, which pursue aggressive policies of gaining global competitive advantages by means of undervalued exchange rates. As a consequence, SWFs are no longer homogenous financial entities. Now the total assets of SWFs make 7.421 trillion USD, includingassets worth 4.168 trillion USD (56.16\%) associated with oil and gas. The central role is played bySWFs of the Persian Gulf (2.878 trillion USD)[14].

By purpose, SWFs can be broken nowinto five types: stabilization funds, saving funds, reserve investment corporations, development funds and contingent pension reserve funds. Neo-protectionist capacities are specific to only stabilization funds, designed to isolate the budget and overall economy from fluctuations of prices for primary resources [5, 
p.313; 3, p.31]. The key instrument by which SWF impact on a domestic economy is made is exchange rate. Accumulation of hard currencies inside countries strengthens national currencies, whereas their increasing rates lower the foreign competitiveness of home-made goods on account of their high cost; therefore, it is very important to have hard currency accumulations allocated in structural development of the economy and investment.

The sovereign demand for assets used to be associated with the policy of currency reserves pursued by central banks, which changed radically as the financial globalization advanced. It was transformation of SWFs into a source of global change in the sphere of investment and capital flows that caused the need for revising the concept of sovereign demand for assets as the one limited by the functional competence of central banks.

The operation specifics of SWFs are affected by a number of destabilizing factors in the global economy, such as devalued global interest rates, pressures on euro and the decreasing competitiveness of European goods, the sustaining link of Asian currencies to the falling dollar, the inflexible growth of exchange rate in many countries etc.

Bearing in mind that SWF grow most rapidly in size and numbers as the problem of financial imbalances aggravates, SWFs in the conditions of "overheated" economy start to take on the functions of control over the domestic inflation, normally executed by central banks, which is caused by the undervalued exchange rate and the competitive accumulation of currency reserves. This problem can be seen most clearly in the economies based on oil extraction. The scales of SWF activity are a proxy of undervalued exchange rates of leading global exporters.

Another problem faced by SWFs is the distortion of global inflation processes and tendencies in the sphere of imbalances [2]. To begin with, two main models of SWF funds management are most often used worldwide: public model and non-public one. However, SWFs are most often referred to as public institutional investors which operation is related with accumulation of sovereign funds (pools) due to favorable macroeconomic, trade and financial positions of a country and their allocation in foreign or domestic financial and alternative assets, to implement long-term objectives of stable national development. The main tasks of such financial institutes are: support economic stability; eliminate negative effects of market conjuncture; accumulate funds for next generations, with guaranteeing additional stimuli for development to domestic enterprises and high level of social protection of the population today and in future.

Of the main risks caused by the increasing global presence of SWFs, the following ones are emphasized by V. Kozyuk:

Lack of transparence and legitimacy of international accountancy, because SWF operation have not been regulated by far at any of the levels. The researcher emphasizes that while central banks provide regular reports to IMF, SWF operation is not subject to jurisdiction of international organizations like IMF, World Bank or Bank of International Settlements; as a result, the global supervision of their operation has rather scientific than official character [2, p.427]. We are inclined to interpret this situation as a step towards defending economic sovereignty, which, in spite of the risks caused by the increasing uncertainties for the rest of global players, lays the fundament for reconfiguration of the existing asymmetry in balancing the interests of developed and developing countries. Moreover, in this we discern the signs of the increasing dependence on resources, because the lion share of SWF founders are countries exporting energy resources (UAE, Norway, Saudi Arabia, Kuwait, Russia, Libya, Qatar, Algeria, Brunei, Malaysia, USA, Canada, Nigeria, Iran, Azerbaijan, Oman, Timor, Venezuela, Trinidad and Tobago) and Asian countries (Singapore, China, South Korea, Taiwan);

- Political engagement that can encourage the occurrence of financial protectionism, which, if extrapolatedon the current and predicted scopes of SWFs, endangers financial globalization per se, with destructive consequences for the global trade, capital flows and capabilities to finance payment imbalances [2, p.427]. Accepting V. Kozlyuk's thesis about 
the occurrence of new sources of risk for the financial stability, we, nevertheless, propose an impartial interpretation of this process as an evidence that countries claiming for the changing role in the contemporary geo-economic space are actively seeking for instruments capable to protect their own economic interests, which were obviously used by developed countries at the phase of formation and establishment as global leaders.

- Financial interference, which mechanism is mediated by the operation of SWFs and which allows some countries to invade financial systems of other ones, causingboth economic and political consequences [2, p.428];

- Concentration of the sovereign demand on assets. Because the overwhelming majority of countries founding SWFs have at their disposal the largest monetary reserves, the sources of demand for assets undergo radical transformation. The sovereign demand for assets begins to catch up with the private one and may sometimes outpace it. According to V. Kozlyuk, when a country has large monetary reserves in possession, combined withSWFs, this will threaten the global financial system with high risks in case of any change in demand and supply [2, p.428]. Agreeing with the author's concern that any process of correcting global financial imbalances will be increasingly more dependent on the character of the sovereign demand for assets, we need to say that this process will be gradual, and will be an objective step towards multi-polarity.

The changing sensitivity of sovereign investment funds to risk/profit ratio and the scale of the investment horizon depends on a fund raising source: funds founded on profits from sales of oil have the largest impact on risky assets, they are capableto invest long-term, they have lower risk, and they seek for funds based on surplus from trade with goods; and the lowest level of risk, even a negative one, will be characteristic of funds based on flows of capital, which have to invest short-term to have the capacity for flexible reaction on the changing situation.

We agree with the opinion of experts from Stanford Economic School that rise and development of SWFs gives evidence of the increasing global tendency towards direct government participation in corporate activities, which is named "new mercantilism" $[4$, p.215;12]. The worsening economic situation in Europe and the lesser possibilities for U.S. to lend abroad in the conditions of sub-prime mortgage crisis decreased global growth rates and cut oil prices. If this affects the current account surpluses of oil exporters, the current accounts of Asian countries will obviously be improved. Besides that, some countries, instead of using foreign currency reserves to implement monetary policies and react on the cessation of capital flows, tend to transfer the surplus of these reserves to SWFs in order to invest diversified assets in foreign currencies. Also, considerable reserves in foreign currencies cause the growing supply of money, thus entailing inflation. This may have extremely negative implications in countries like China, Vietnam or Indonesia, which, having adopted the exportoriented model of economic growth, seek for competitive prices for home-made goods. To have this situation prevented, the government withdraws extra liquidity through sterilization of assets. This will be possible to dowhen the interest rate paid on government bonds issued for sterilization of extra reserves in foreign currencies is not higher than the incomes on assets in which the reserves are invested.A part of the reserves is, therefore, transferred to SWFs which purpose is to invest in a multiplicity of assets that are capable forgenerating a higher income, although often a risky one.

Official purchases through SWFs are not considered as harmful in economic literature, but this argument seems to us rather contradictory, because the main purpose of SWFs is to transfer savings abroad, which will decrease the value of national currency and preserve a large surplus in the current account. In this sense, foreign investment of SWFs is positively a currency manipulation. This can be excused when a non-renewable resource is exported, although even then there must be international agreements imposing limitations on such action.A major part of SWFs activities involved investment in developed countries, intended to cope with economic and political problems. This was accompanied by the 
increasing protectionist tendencies in the investment policies of countries that arerecipientsof capital.

SWFs are being actively created by not only exporters of primary commodities, but by oil importers as well. These are countries that either effectively increase exports of goods (such as Japan, Ireland, China, South Korea) or pursue expansion policies at global financial and information markets, including Singapore and Hong Kong. A positive balance of foreign trade may occur due to export expansions, reduced prices for imported goods, changed exchange rates or administrative limitations on imports. When a government with the positive account of current transactions accumulates more reserves than it needs to achieve short-term goals, it tends to create a SWF in order to administer these "additional" reserves.

The difference between monetary incomes and expenditures is not covered by internal investment because industrial infrastructures fail to absorb a surplus of money. To eliminate inflation effects from the increasing monetary mass, a surplus of hard currency has to be "sterilized" by transferring it abroad. The problem of external payment imbalances obviously has global and system nature. The persisting positive payment balance in some countries along with the permanently negative external payment balance in other ones (high payment deficit in U.S. and high surpluses in China) causes the uneven cross-country distribution of capital, taking on the threatening and chromic character. The correction of global imbalances launched in 2008 is a long and nonlinear process.

Therefore, SWF is a consequence of imbalanced global financial flowsas well as an instrument to eliminate imbalances. Funds like this are created in countries with either negative or positive payment balance, including ones where these figures are the highest. It is quite logical that the largest amounts of sovereign money are concentrated in countries with positive balances. SWFs help in mitigating undesired effects from the foreign currency surplus by way of their "sterilization". In 2013, due to the fall of oil prices, countries like Norway, Russia and Singapore could not enter the top-10 countries with the highest surplus. They were replaced by Qatar, UAE, the Republic of Korea and Taiwan. The economic effects from the oil shock are being rapidly materialized. Basically, the rapidly falling oil prices cause redistribution of real incomes from investors to consumers in importing countries like Japan, EU members and U.S., which decreased the negative balance. In countries with developed and flexible economies, where exchange rates are formed by the market mechanism of supply and demand, the increased exchange rate of national currency (just like the decreased effectiveness of exports of goods) causes rapid transfers of capital to other spheres. Thus, in 2013 China could decrease the negative balance by way ofincreased investment, stimulating tax and budget policy focused on growth of spending, boost of lending and growth of prices for assets. Besides that, developed countries like Germany that has the highest positive balance, as well as Switzerland and the Netherlands, are active participants of global financial and economic relations. Therefore, they have no need in creating special funds to compensate possible losses in case of the changed conjuncture at some commodity markets: the adaptability of domestic economy and the mobility of resources can fully protect and secure it $[7 ;$ p. 9].

Conclusions.Irrespective of the declared objectives, SWF is, in fact, an effective actor in the economic policy implementation. Raising of additional funds in form of SWFis caused by the need to guarantee future government spending related with ageing of the population and seeking for an adaptive social model. Therefore, the expansion of SWFs is a reflection of the combination of global financial imbalances, global financial integration and new capabilities in the global investment sphere.

\section{References}

1. Dyba M. (2015) 'Suverenni fondy na rynku kapitaliv' [Sovereign funds in thecapital market], Finances of Ukraine 8: 56-73.

2. Kozyuk V. (2009), 'Monetarni zasady hlobal'noyi finansovoyi stabil'nosti' 
[Monetary fundamentals of global financial stability], TNEU, "Ekonomichna dumka": $728 \mathrm{~s}$.

3. Panchenko V., ReznikovaN. (2017) 'Vid protektsionizmu do neoprotektsionizmu: novi vymiry rehulyuvannya $\mathrm{v}$ umovakh liberalizatsiyi' [From protectionism to neo-protectionism: new dimensions of regulation in the conditions of liberalization], Mizhnarodna ekonomichna polityka 2(27): 28-46.

4. Panchenko V. (2018) 'Hlobal'ni vymiry neoprotektsionizmu: teoriya i praktyka' [Global dimensions of neo-protectionism: theory and practice], Ahrar Media Hrup: $618 \mathrm{~s}$.

5. Reznikova N. (2018) 'Ekonomichna neozalezhnist' krayin v umovakh hlobal'nykh transformatsiy' [Economic neo-dependence of Countries in the Context of Global Transformations], Ahrar Media Hrup: 460s.

6. Reznikova N., Ivashchenko O. (2016) 'Neozalezhnist' ukrayins'koyi ekonomiky yak proyav vyklykiv ekonomichniy bezpetsi: perspektyvy strukturnoy itransformatsiyi ta makroekonomichnoyi stabilizatsiyi' [Neo-dependence of the Ukrainian economy as a manifestation of challenges to economic security: prospects of structural transformation and macroeconomic stabilization], Ekonomika ta derzhava 2: 4-8.

7. Reznikova N., Ivashchenko O. (2017) 'Perspektyvy formuvannya novykh tsentriv ekonomichnoho zrostannya $\mathrm{v}$ umovakh novoyi normy svitovoyi ekonomiky yak proya neozalezhnosti' [Prospects for the emerging new centers of economic growth in the context of new norm of the global economy: a manifestation of neo-dependence], Investytsiyi: praktyka ta dosvid 11: 5-9.

8. Shpyl'ka O., Sorokina O. (2012) 'Rol' fondiv suverennoho bahatstva v systemi hlobal'noyi finansovoyi stabil'nosti' [The role of sovereign wealth funds in the system of global financial stability]. Available at: http://nauka.kushnir.mk.ua/?p=10575.

9. Beck R., Fidora M.(2008) 'The Impact of Sovereign Wealth Funds on Global Financial Markets'. Available at: $<$ https://www.ecb.europa.eu/pub/pdf/scpops/ecbocp91.pdf?cf1d54411b5d38ec73277c2d7827 $3 \mathrm{a} 31>$.

10. Bortolotti B., Fotak V., Megginson W.L. (2015) 'The Rise of Sovereign Wealth Funds: Definition, Organization, and Governance'. Available at: https://www.unibocconi.eu/wps/wcm/connect/fbd0c50e-0402-4992-9a2f0a46d3105261/SWF-PPP-Palgrave-1.pdf?MOD=AJPERES.

11. BulatovaO. (2016) 'Regionalization of the World Economy', VisnykMariupol's'kohoderzhavnohouniversytetu. Seriya: Ekonomika 12: 153-161.

12. Fiechter J.(2010) 'The French Strategic Investment Fund: A Creative Approach to Complement SWF Regulation of Mere Protectionism?', Journal of Applied Economy3: 59-77/

13. Santiso J.(2009) 'Sovereign Development Funds: Key financial actors of the shifting wealth of nations'. Available at: <https://www.oecd.org/dev/41944381.pdf>.

14. Sovereign Wealth Fund Rankings(2018). Available at: <https://www.swfinstitute.org/sovereign-wealth-fund-rankings/>.

15. Sovereign Wealth Funds: Aspects of Governance Structures and Investment Management(2013). Available at: <https://www.imf.org/external/pubs/ft/wp/2013/wp13231.pdf>. 